\title{
Minireview
}

\section{Rhizobial Strategies to Enhance Symbiotic Interactions: Rhizobitoxine and 1-Aminocyclopropane-1-Carboxylate Deaminase}

\author{
SHIN OKAZAKI ${ }^{1}$, NORIYUKI NUKUI ${ }^{1}$, MASAYUKI SUGAWARA ${ }^{1}$ and KIWAMU MINAMISAWA ${ }^{1 *}$ \\ ${ }^{1}$ Graduate School of Life Sciences, Tohoku University, Katahira, Aoba-ku, Sendai 980-8577, Japan
}

(Received March 31, 2004-Accepted April 23, 2004)

\begin{abstract}
Nitrogen-fixing nodules are formed as a result of a series of interactions between rhizobia and leguminous plants. Bradyrhizobium elkanii produces rhizobitoxine, an enol-ether amino acid, which has been regarded as a phytotoxin because it causes chlorosis in soybeans. However, recent studies have revealed that rhizobitoxine plays a positive role in establishing symbiosis between $B$. elkanii and host legumes: rhizobitoxine enhances the nodulation process and nodulation competitiveness by inhibiting ethylene biosynthesis in host roots. In addition, the gene for 1-aminocyclopropane-1-carboxylate (ACC) deaminase was recently found in some rhizobia, such as Mesorhizobium loti, Bradyrhizobium japonicum and Rhizobium sp. ACC deaminase also facilitates symbiosis by decreasing ethylene levels in host roots. The cumulative evidence reveals general strategies by which rhizobia produce an inhibitor and an enzyme to decrease ethylene levels in host roots and thereby enhance nodulation. In this review, we compare these strategies and discuss how they function and have evolved in terms of genetics, biochemistry, and ecology. These rhizobial strategies might be utilized as tools in agriculture and biotechnology.
\end{abstract}

Key words: ACC deaminase, ethylene, legume, rhizobia, rhizobitoxine

In the symbiotic nitrogen-fixation process, bacteria of the family Rhizobiaceae convert atmospheric dinitrogen $\left(\mathrm{N}_{2}\right)$ to ammonia $\left(\mathrm{NH}_{3}\right)$, which can be effectively utilized by host legume plants. The taxonomy within the family Rhizobiaceae is still in a state of flux, although the major taxa are members of the alpha-subdivision of the Proteobacteria $^{73,89,90)}$. The family Rhizobiaceae currently includes six genera: Rhizobium, Sinorhizobium, Mesorhizobium, Allorhizobium, Azorhizobium, and Bradyrhizobium, which are collectively referred to as rhizobia. They have the ability to infect the roots of legumes and to produce nodules. The differentiated forms of rhizobia in the nodule, called bacteroids, fix atmospheric nitrogen into ammonia and export the fixed nitrogen to the host plant ${ }^{42)}$. Symbiotic

\footnotetext{
* Corresponding author; E-mail: kiwamu@ige.tohoku.ac.jp, Tel: +81-22-217-5684, Fax: +81-22-217-5684

Abbreviations: ACC, 1-aminocyclopropane-1-carboxylate; AVG, aminoethoxyvinylglycine.
}

nitrogen fixation is of great importance not only in the production of leguminous crops but also in the global nitrogen cycle. Nitrogen is a major limiting factor for most plant species in the biosphere. Application of $\mathrm{N}$ fertilizers to fields increases crop production. However, excessive use of $\mathrm{N}$ fertilizers often causes environmental problems, including water pollution by $\mathrm{NO}_{3}{ }^{-}$and the evolution of a greenhouse gas, nitrous oxide $\left(\mathrm{N}_{2} \mathrm{O}\right)$, into the atmosphere ${ }^{34,53)}$. Effective use of biological nitrogen fixation results in an ideal cropping system with decreased impact on the environment through decreased application of $\mathrm{N}$ fertilizers ${ }^{3)}$.

\section{Outline of nodulation process by rhizobia}

Nitrogen-fixing nodules are formed as a consequence of a series of interactions between rhizobia and leguminous host plants ${ }^{15)}$. The symbiotic partners show a high degree of mutual specificity, mediated by the exchange of chemical 


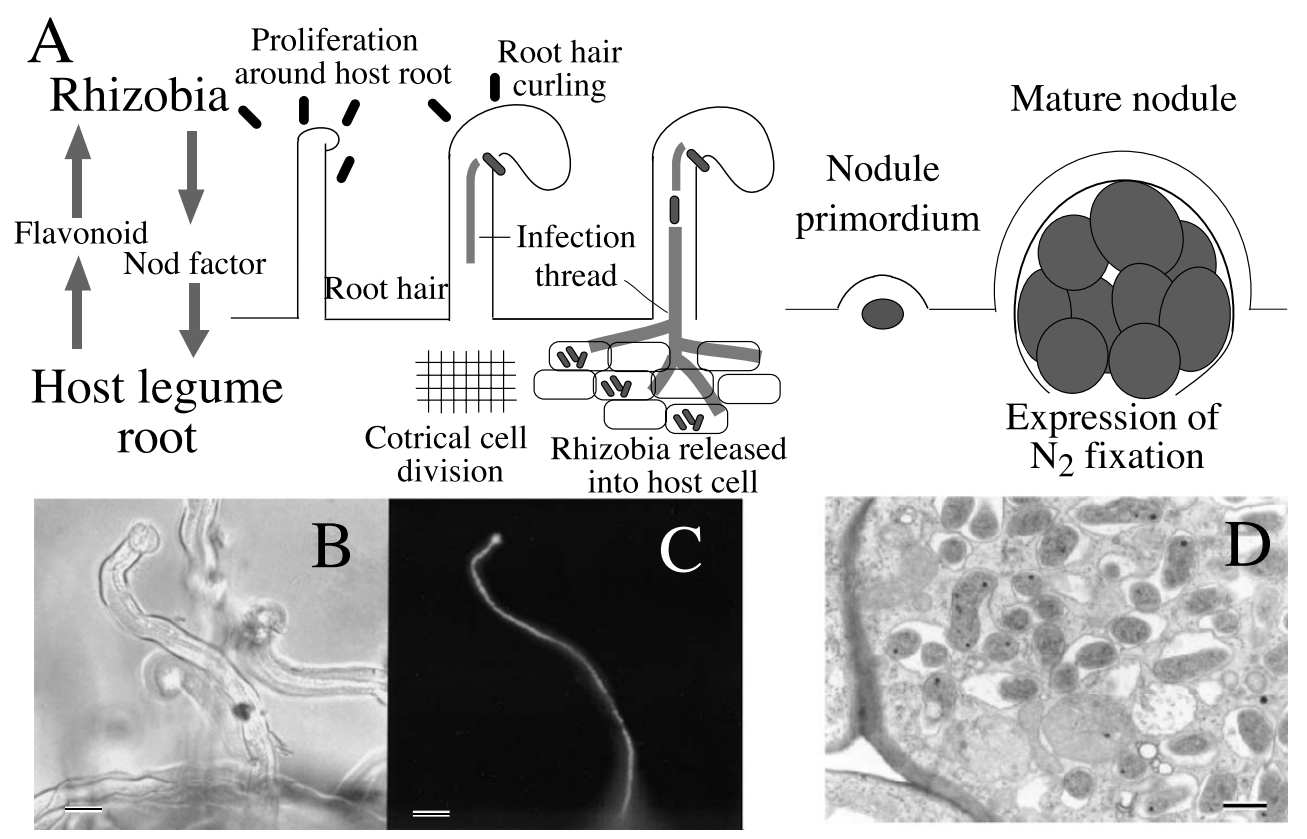

Fig. 1. Nodulation by rhizobia. (A) Scheme of chemical signal exchanges and infection processes involving rhizobia. (B) Root-hair curing in Lotus japonicus. (C) Mesorhizobium loti cells tagged with constitutive gfp gene in an infection thread in the root hair shown in panel (B). (D) M. loti bacteroids in infected cells of a mature L. japonicus nodule. Bar indicates $10 \mu \mathrm{m}$ (B, C) and $1 \mu \mathrm{m}$ (D).

signals ${ }^{77,79)}$. The plant signals, flavonoids excreted by the roots, activate the expression of nodulation genes in rhizobia, resulting in the production of rhizobial lipochitooligosaccharide signals called Nod factors (Fig. 1A). These Nod factors in return induce root-hair curling and cortical cell division in the roots of the host legume (Fig. 1A). Simultaneously, the Nod factors in the presence of rhizobia induce the root cells to form an infection thread (a tube-like structure growing from the root hair tip toward the root cell body) through which the rhizobia enter, travel down a root hair, and are thereafter released into the dividing cortical cells of legume roots (Fig. 1A-C). Rhizobial cells released in the plant cells differentiate into their symbiotic form, nitrogen-fixing bacteroids (Fig. 1AD). Although legumes form root nodules mainly in response to Nod factors, it has been thought that the plant perception of endogenous signals, particularly plant hormones, is also important for the establishment of proper symbiotic interactions between rhizobia and legumes ${ }^{6}$.

\section{Effect of ethylene on nodulation}

Ethylene is a plant hormone that functions as a regulator in many aspects of plant life. Ethylene is produced and sensed in response to a wide variety of environmental and developmental cues, including germination, flowering, drought, pathogen attack, and nodulation ${ }^{1,78)}$.

In particular, ethylene inhibits infection of rhizobia and nodulation of most legumes, as shown by many studies (Table 1). Exogenously applied ethylene or ethylene precursor inhibits nodulation in many legumes. In Pisum sativum, exogenous ethylene application inhibits elongation of infection threads into the inner cortex ${ }^{37)}$. In P. sativum, endogenous ethylene exerts positions on nodule meristem morphogenesis ${ }^{27}$. Inhibition of ethylene synthesis and responses has been shown to enhance nodule formation in Medicago truncatula ${ }^{59)}$, Medicago sativa ${ }^{56,70)}$, Lotus japonicus ${ }^{4,56)}$, P. sativum $^{25,43)}$, and Macroptilium atropurpureum $^{56}$. In addition, a hypernodulating mutant of Medicago truncatula has ethylene-insensitive phenotypes ${ }^{68)}$. Unlike in most legume species, however, ethylene may not play a significant role in the nodulation of modern soybean cultivars $^{30,75)}$.

Ethylene evolution in legume roots increases after application of rhizobial cells ${ }^{38,82)}$, Nod factor ${ }^{91)}$, nitrate ${ }^{5,39)}$, and illumination $^{36)}$, suggesting that these environmental factors control nodulation through their effects on the levels of ethylene. 
Table 1. Effects of ethylene, ethylene precursors, and inhibitors on nodulation of legumes by rhizobia

\begin{tabular}{|c|c|c|c|c|}
\hline Legume (rhizobia) & Cultivar, ecotype, mutant & Reagent or treatment ${ }^{\mathrm{a}}$ & Effects on nodulation & Reference \\
\hline \multirow{8}{*}{$\begin{array}{l}\text { Glycine max } \mathrm{L} \text {. } \\
\text { (Bradyrhizobium japonicum) }\end{array}$} & cv. Ransom & Ethylene gas & No effect on nodule number & 37 \\
\hline & cv. Tracy & Ethephon & No effect on nodule number & 30 \\
\hline & cv. Hakuchou & Rhizobial inoculation & Enhanced production of ethylene & 82 \\
\hline & cv. Bai tie jia qing & \multirow[t]{2}{*}{ Ethylene gas } & No effect on nodule number & \multirow[t]{2}{*}{94} \\
\hline & cv. Gong jiao 6308-1 & & Decrease in nodule number & \\
\hline & cv. Bragg & STS & $\begin{array}{l}\text { Restoration of nitrate inhibition of } \\
\text { nodulation }\end{array}$ & 41 \\
\hline & cv. Hobbit 87 & ACC/STS & No effect on nodule number & 75 \\
\hline & cv. Enrei & $\mathrm{ACC} / \mathrm{AVG} / \mathrm{STS}$ & No effect on nodule number & 56 \\
\hline \multirow{4}{*}{$\begin{array}{l}\text { Lotus japonicus } \\
\text { (Mesorhizobium loti) }\end{array}$} & \multirow[t]{4}{*}{ Ecotype B-129 Gifu } & ACC & Decrease in nodule number & \multirow[t]{2}{*}{56} \\
\hline & & AVG/STS & Increase in nodule number & \\
\hline & & AVG & Increase in nodule number & 4 \\
\hline & & AVG, STS & Enhancement of $N I N$ gene expression & 55 \\
\hline \multirow{2}{*}{$\begin{array}{l}\text { Macroptilium atropurpureum } \\
\text { (Bradyrhizobium japonicum) }\end{array}$} & \multirow[t]{2}{*}{ cv. Siratro } & $\mathrm{ACC}$ & Decrease in nodule number & \multirow[t]{2}{*}{56} \\
\hline & & AVG/STS & Increase in nodule number & \\
\hline \multirow{6}{*}{$\begin{array}{l}\text { Medicago sativa } \mathrm{L} \text {. } \\
\text { (Sinorhizobium meliloti) }\end{array}$} & cv. Aragon & Rhizobial inoculation & Enhanced production of ethylene & 38 \\
\hline & cv. AS-R3 & AVG & Increase in nodule number & 70 \\
\hline & \multirow[t]{2}{*}{ cv. Aragon } & AVG & $\begin{array}{l}\text { Restoration of nitrate inhibition of } \\
\text { nodulation }\end{array}$ & 40 \\
\hline & & STS & $\begin{array}{l}\text { Restoration of nitrate inhibition of } \\
\text { nodulation }\end{array}$ & 5 \\
\hline & \multirow[t]{2}{*}{ cv. Du Puits } & $\mathrm{ACC}$ & Decrease in nodule number & \multirow[t]{2}{*}{56} \\
\hline & & AVG/STS & Increase in nodule number & \\
\hline \multirow{5}{*}{$\begin{array}{l}\text { Medicago truncatula } \\
\text { (Sinorhizobium meliloti) }\end{array}$} & \multirow[t]{5}{*}{ cv. Jemalong genotype A17 } & $\mathrm{ACC}$ & Decrease in nodule number & 68 \\
\hline & & & Decrease in nodule number & \multirow[t]{4}{*}{59} \\
\hline & & & Fewer infection threads & \\
\hline & & AVG & Increase in nodule number & \\
\hline & & & More infection threads & \\
\hline \multirow{4}{*}{$\begin{array}{l}\text { Phaseolus vulgaris } \mathrm{L} . \\
\text { (Rhizobium } \mathrm{sp} .)\end{array}$} & \multirow[t]{2}{*}{ var. Pencil Podded Black Wax } & Ethylene gas & Decrease in nodule number & \multirow[t]{2}{*}{22} \\
\hline & & & Decrease in nitrogen fixation & \\
\hline & \multirow[t]{2}{*}{ cv. Harvester } & Ethephon & Decrease in nodule number & \multirow[t]{2}{*}{84} \\
\hline & & AVG/AOA/cobalt & Increase in nodule number & \\
\hline $\begin{array}{l}\text { Melilotus alba } \\
\text { (Sinorhizobium meliloti) }\end{array}$ & U389 & Ethylene gas & Decrease in nodule number & 37 \\
\hline \multirow[t]{8}{*}{$\begin{array}{l}\text { Pisum sativum } \mathrm{L} . \\
\text { (Rhizobium leguminosarum } \\
\text { bv. viciae) }\end{array}$} & cv. Sutton's Show Perfection & Ethrel & $\begin{array}{l}\text { Decrease in nodule number } \\
\text { Local regulation }\end{array}$ & 9 \\
\hline & \multirow[t]{3}{*}{ cv. Feltham First } & \multirow[t]{3}{*}{ Ethylene gas } & Inhibition of root extension & \multirow[t]{3}{*}{19} \\
\hline & & & Decrease in nodule number & \\
\hline & & & Decrease in nitrogen fixation & \\
\hline & \multirow[t]{4}{*}{ cv. Sparkle } & STS & $\begin{array}{l}\text { Restoration of nitrate/light inhibition } \\
\text { of nodulation }\end{array}$ & \multirow[t]{2}{*}{36} \\
\hline & & Nitrate & Enhanced production of ethylene & \\
\hline & & Ethylene gas & $\begin{array}{l}\text { Decrease in nodule number, blockage } \\
\text { of infection thread elongation in inner } \\
\text { cortex }\end{array}$ & 37 \\
\hline & & $\mathrm{AVG} / \mathrm{Ag}_{2} \mathrm{SO}_{4}$ & $\begin{array}{l}\text { Control of the position of nodule } \\
\text { primordium formation }\end{array}$ & 27 \\
\hline
\end{tabular}


Table 1. Conutinued

\begin{tabular}{|c|c|c|c|c|}
\hline Legume (rhizobium) & Cultivar, ecotype, mutant & Reagent or treatment ${ }^{\mathrm{a}}$ & Effects on nodulation & Reference \\
\hline & & AVG & Increase in mature nodule number & 25 \\
\hline & & BAP (cytokinin) & Decrease in nodule number & 43 \\
\hline & & & Enhanced production of ethylene & \\
\hline & & AVG & Increase in nodule number & \\
\hline & & $\mathrm{Ag}_{2} \mathrm{SO}_{4}$ & Changed nodule distribution on root & \\
\hline & cv. Rondo & Ethylene gas & Decrease in nodule number & 37 \\
\hline \multirow{2}{*}{$\begin{array}{l}\text { Sesbania rostrata } \\
\text { (Azorhizobium caulinodans) }\end{array}$} & \multirow[t]{2}{*}{ cv. Brem } & $\mathrm{Ag}_{2} \mathrm{SO}_{4}$ & Induction of indeterminate nodules & 14 \\
\hline & & $\mathrm{ACC}$ & Induction of determinate nodules & \\
\hline \multirow{2}{*}{$\begin{array}{l}\text { Trifolium repens } \mathrm{L} . \\
\text { (Rhizobium trifolii) }\end{array}$} & \multirow[t]{2}{*}{ cv. Huia } & \multirow[t]{2}{*}{ Ethylene gas } & Decrease in nodule number & 19 \\
\hline & & & Decrease in nitrogen fixation & \\
\hline $\begin{array}{l}\text { Vicia sativa } \\
\text { (Rhizobium leguminosarum } \\
\text { bv. viciae) }\end{array}$ & spp. nigra & $\mathrm{AVG} / \mathrm{Ag}_{2} \mathrm{SO}_{4}$ & $\begin{array}{l}\text { No effect on nod factor induced root hair } \\
\text { tip growth }\end{array}$ & 27 \\
\hline \multirow{2}{*}{$\begin{array}{l}\text { Vigna radiata } \mathrm{L} \text {. } \\
\text { (Bradyrhizobium elkanii) }\end{array}$} & \multirow[t]{2}{*}{ cv. Berkan } & Ethephon & Decrease in nodule number & 10 \\
\hline & & STS/cobalt & Increase in nodule number & \\
\hline \multirow[t]{2}{*}{$\begin{array}{l}\text { Glycine max } \mathrm{L} \text {. } \\
\text { (Bradyrhizobium japonicum) }\end{array}$} & $\begin{array}{l}\text { cv. Hobbit } 87 \text { T119N54 (etr1-1) } \\
\text { mutant (ethylene insensitive) }\end{array}$ & & Normal nodulation & \multirow[t]{2}{*}{75} \\
\hline & $\begin{array}{l}\text { cv. Williams } 82 \text { NOD1-3 (rj7) } \\
\text { mutant (hypernodulation) }\end{array}$ & $\mathrm{ACC}$ & No effect on nodule number & \\
\hline \multirow[t]{2}{*}{$\begin{array}{l}\text { Lotus japonicus } \\
\text { (Mesorhizobium loti) }\end{array}$} & \multirow{2}{*}{$\begin{array}{l}\text { Ecotype B-129 Gifu transformed } \\
\text { with an ethylene receptor gene } \\
\text { (reduced ethylene sensitivity) }\end{array}$} & & $\begin{array}{l}\text { Increase of infection threads and nodule } \\
\text { primordia }\end{array}$ & \multirow[t]{2}{*}{55} \\
\hline & & & Enhancement of $N I N$ gene expression & \\
\hline \multirow{5}{*}{$\begin{array}{l}\text { Medicago truncatula } \\
\text { (Sinorhizobium meliloti) }\end{array}$} & \multirow{3}{*}{$\begin{array}{l}\text { Sickle mutant } \\
\text { (ethylene insensitive) }\end{array}$} & & Hyperinfection & 68 \\
\hline & & & Blockage of calcium spiking in root cells & 59 \\
\hline & & & $\begin{array}{l}\text { Control of the position of nodule } \\
\text { primordium formation }\end{array}$ & 69 \\
\hline & sickle/sunn double mutant & & $\begin{array}{l}\text { Control of the position of nodule } \\
\text { primordium formation }\end{array}$ & \\
\hline & sunn mutant (hypernodulation) & $\mathrm{ACC}$ & Decrease in nodule number & \\
\hline \multirow{5}{*}{$\begin{array}{l}\text { Pisum sativum } \mathrm{L} \text {. } \\
\text { (Rhizobium leguminosarum } \\
\text { bv. viciae) }\end{array}$} & $\begin{array}{l}\text { cv. Sparkle sym5 mutant } \\
\text { (low or non-nodulation) }\end{array}$ & $\mathrm{AVG} / \mathrm{Ag}_{2} \mathrm{SO}_{4} / \mathrm{Co}\left(\mathrm{NO}_{3}\right)_{2}$ & $\begin{array}{l}\text { Restoration of nodulation in sym } 5 \\
\text { mutants }\end{array}$ & 13 \\
\hline & $\begin{array}{l}\text { Sparkle E107 ( } b r z) \text { mutant } \\
\text { (low nodulation mutant) }\end{array}$ & $\mathrm{AVG} / \mathrm{Ag}_{2} \mathrm{SO}_{4}$ & Restoration of nodulation in $b r z$ mutants & 24 \\
\hline & $\begin{array}{l}\text { cv. Sparkle E135F (sym 13) } \\
\text { mutant (small ineffective } \\
\text { nodule) }\end{array}$ & Ethylene gas & Decrease in nodule number & \multirow[t]{2}{*}{37} \\
\hline & $\begin{array}{l}\text { cv. Rondo nod-3 mutant } \\
\text { (hypernodulation) }\end{array}$ & Ethylene gas & Decrease in nodule number & \\
\hline & $\begin{array}{l}\text { cv. Sparkle R50 (sym 16) } \\
\text { mutant (low nodulation) }\end{array}$ & AVG & Acceleration of nodulation development & 25 \\
\hline \multirow{3}{*}{$\begin{array}{l}\text { Vicia sativa } \\
\text { (Rhizobium leguminosarum } \\
\text { bv. viciae) }\end{array}$} & \multirow[t]{3}{*}{$\begin{array}{l}\text { ssp. nigra tsr mutant } \\
\text { (thick, short roots) }\end{array}$} & AVG & $\begin{array}{l}\text { Restoration of normal nodulation in } t s r \\
\text { mutant }\end{array}$ & 99 \\
\hline & & Ethephon & Tsr (thick, short root) phenotype & \multirow[t]{2}{*}{91} \\
\hline & & AVG & Restoration of normal root phenotype & \\
\hline
\end{tabular}

ACC, 1-aminocyclopropane-1-carboxylic acid; AOA, aminooxyacetic acid; AVG, L- $\alpha$-(2-aminoethoxyvinyl) glycine; BAP, 6-benzyl-aminopurine; STS, silver thiosulfate 


\section{Chlorosis induction by rhizobitoxine produced by soybean bradyrhizobia}

In 1956, Erdman et al. ${ }^{11)}$ first reported that certain strains of rhizobia induce chlorosis in new leaves of soybeans. Owens and colleagues ${ }^{65,66)}$ purified the toxic compound from nodule extracts and culture media of Rhizobium japonicum (now Bradyrhizobium elkanii) and demonstrated that the compound is phytotoxic to soybeans and other plant species ${ }^{31,60)}$. The toxic compound was later called rhizobitoxine. Among soybean bradyrhizobia, all strains of Bradyrhizobium elkanii (formerly DNA homology group II) produce rhizobitoxine, whereas those of $B$. japonicum (formerly DNA homology group I) do not produce rhizobitoxine at all ${ }^{29,46,47,49)}$. Thus, rhizobitoxine production is a general feature of B. elkanii, among which strains USDA94 and USDA $76^{\mathrm{T}}$ are high producers of rhizobitoxine in culture ${ }^{46}$. A plant pathogen, Burkholderia andropogonis, is also known to be a rhizobitoxine producer. The pathogen causes chlorotic symptoms in corn and sorghum, presumably as a result of rhizobitoxine production in planta ${ }^{511}$.

Rhizobitoxine has therefore been regarded as a phytotoxin that causes chlorosis symptoms in soybeans. However, recent studies have revealed that rhizobitoxine has a positive role in the establishment of symbiosis between B. elkanii strains and their host legumes (see below).

\section{Biochemical functions of rhizobitoxine}

The structure of rhizobitoxine was solved in $1972^{64)}$. Rhizobitoxine is an enol-ether amino acid (2-amino-4-[2amino-3-hydroxypropoxy]-trans-3-butenoic acid) with a molecular weight of 190. The first biochemical function identified for rhizobitoxine was that of an inhibitor of $\beta$ - cystathionase in the methionine biosynthesis pathway ( $\beta$ cystathionase, E.C.4.4.1.8) (Fig. 2). $\beta$-Cystathionase catalyzes the conversion of cystathionine to homocysteine, pyruvate, and ammonium. As an analog of cystathionine, rhizobitoxine irreversibly inhibits $\beta$-cystathionase in bacteria $^{61)}$ and plants ${ }^{16)}$.

Yasuta et al. ${ }^{97)}$ found that rhizobitoxine also strongly inhibits 1-aminocyclopropane-1-carboxylate (ACC) synthase (E.C.4.4.1.14) in the ethylene biosynthesis pathway (Fig. 2), which can explain the early observation of rhizobitoxine inhibition of ethylene evolution in apple tissues ${ }^{62}$. ACC synthase is the rate-limiting enzyme in ethylene biosynthesis in plants, catalyzing the conversion of S-adenosylmethionine to ACC. A closely related ethoxy analog of rhizobitoxine, aminoethoxyvinylglycine (AVG), also inhibits ACC synthase $^{7,97)}$. The oxidized form of rhizobitoxine (dihydrorhizobitoxine, Fig. 3) is approximately $99 \%$ less potent than rhizobitoxine as an inhibitor of ACC synthase, so the double bond between $\mathrm{C} 3$ and $\mathrm{C} 4$ may be critical for the inhibition of ACC synthase ${ }^{97)}$.

\section{Positive role of rhizobitoxine production in nodulation}

Rhizobitoxine has been regarded as a phytotoxin ever since the discovery that it induces chlorosis. However, recent studies have shown a positive role of rhizobitoxine in the symbiosis between B. elkanii strains and their host legumes.

Yuhashi et al. ${ }^{98)}$ reported that rhizobitoxine production in B. elkanii USDA94 reduces ethylene evolution from the associated roots of Macroptilium atropurpureum (Siratro) and enhances nodule formation by using B. elkanii USDA94 and its mutant lacking rhizobitoxine production ${ }^{98}$. In partic-

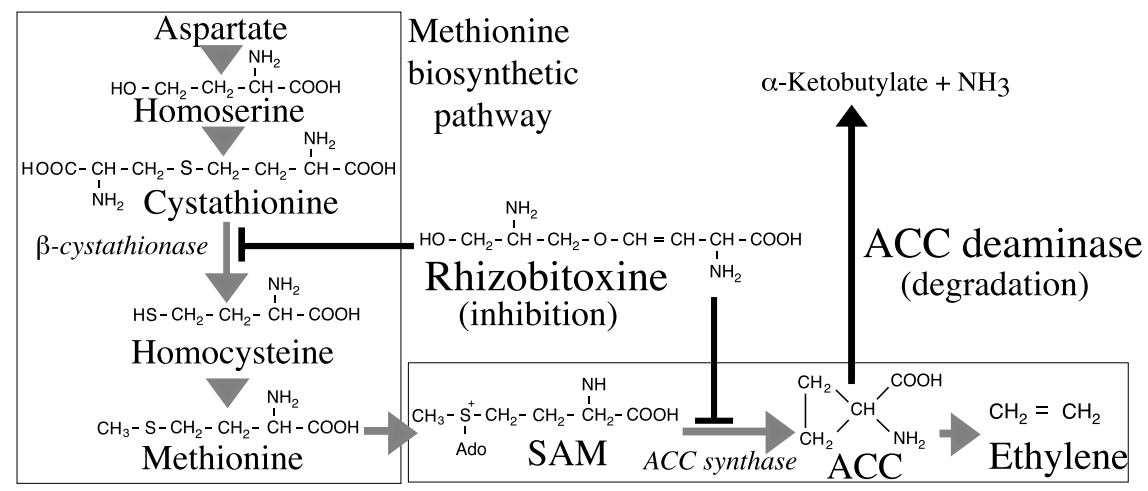

Ethylene biosynthetic pathway

Fig. 2. Target reactions of rhizobitoxine and ACC deaminase. SAM, S-adenosylmethionine; ACC, 1-aminocyclopropane-1-carboxylate. 


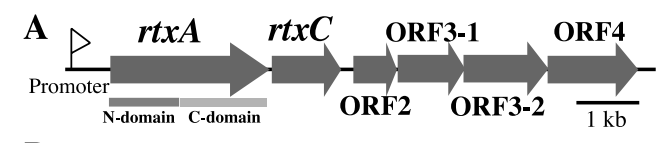

B

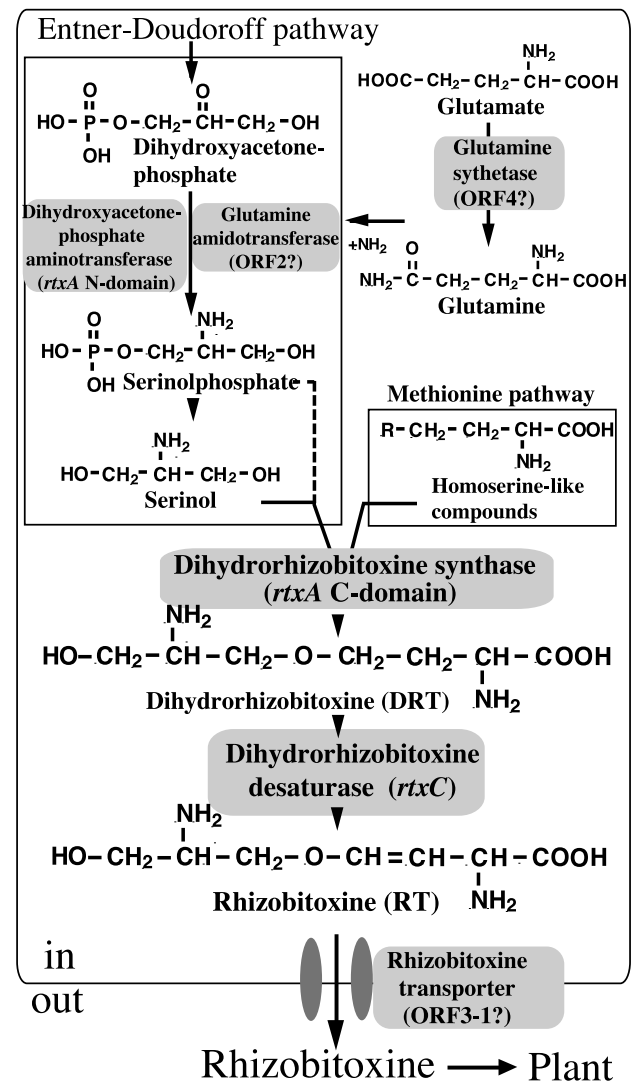

Fig. 3. Rhizobitoxine biosynthesis operon (A) and proposed pathway for rhizobitoxine biosynthesis (B) in Bradyrhizobium elkanii.

ular, the nodulation competitiveness of B. elkanii USDA94 was significantly enhanced by rhizobitoxine production (As for nodulation competitiveness, see below). Duodu et al. ${ }^{10)}$ also reported a positive role of rhizobitoxine in the symbiosis between B. elkanii USDA61 and Vigna radiata (mungbean). Rhizobitoxine-minus mutants of USDA61 formed dramatically fewer mature nodules than the wild-type strain. Interestingly, the rhizobitoxine-minus mutants induced many immature nodules, indicating that the initial stages of root hair infection were not impaired but that the development to mature nodules was obstructed. Therefore, ethylene might affect abortion of the developing nodules in the association between USDA61 and mungbean, and rhizobitoxine production by the bacterium would overcome this effect by inhibiting ethylene biosynthesis.

Another study on rhizobitoxine and nodulation was car- ried out by Parker et al. using Amphicarpaea ${ }^{67}$. Nodulation experiments using B. elkanii USDA61 and its rhizobitoxineminus mutants revealed that efficient nodulation in $A$. edgeworthii but not in $A$. bracteata is highly dependent on rhizobitoxine production.

\section{Rhizobitoxine biosynthesis genes and pathway}

The genes involved in rhizobitoxine biosynthesis have been identified in two B. elkanii strains, USDA61 ${ }^{71}$ and USDA9496). Ruan et al. $^{71)}$ isolated Tn5-induced rhizobitoxine-null mutants of $B$. elkanii USDA61 and identified the $\operatorname{rtx} A$ gene, which is responsible for rhizobitoxine biosynthesis in culture and in planta. Yasuta et al. ${ }^{96)}$ cloned and sequenced the genetic locus involved in rhizobitoxine biosynthesis from B. elkanii USDA94, which produces more rhizobitoxine than USDA61 in culture. B. elkanii USDA94 possesses several ORFs downstream of the $\operatorname{rtx} A$ gene in a single transcriptional unit (RT operon), as shown in Fig. 3A (Sugawara, unpublished results). A large deletion mutant of B. elkanii, USDA94 $\operatorname{rtx}:: \Omega 1$, which lacks $r t x A, r t x C$, and the downstream ORFs, does not produce rhizobitoxine, dihydrorhizobitoxine, or serinol. The latter two compounds have been found to be coproduced with rhizobitoxine and are regarded as intermediates ${ }^{50,63,96)}$. Complementation analyses with cosmids containing an insertional mutagenesis within the putative RT operon suggested that (i) at least $r t x A$ and $r t x C$ are necessary for rhizobitoxine production in $B$. elkanii, (ii) the newly discovered $r t x C$ gene, which is located immediately downstream of the $r t x A$ gene, is involved in desaturation of dihydrorhizobitoxine into rhizobitoxine, and (iii) other ORFs downstream of $r t x C$ affect the levels of production of rhizobitoxine and its intermediates by unknown functions (Fig. 3). Recently, ORFs downstream of $r t x C$ were found to be likely to mediate the incorporation of the amido-N of glutamine into serinolphosphate and to be involved in rhizobitoxine secretion (Sugawara et al. unpublished results) (Fig. 3).

Large amounts of dihydrorhizobitoxine are generally coproduced with rhizobitoxine ${ }^{48,63)}$. However, no conclusive data have been reported on the biological effects of dihydrorhizobitoxine in planta. Okazaki et al. ${ }^{57)}$ demonstrated that dihydrorhizobitoxine production does not affect the phenotypes of $B$. elkanii USDA94 in terms of nodulation competitiveness and chlorosis induction. They thus concluded that desaturation of dihydrorhizobitoxine by an $\operatorname{rtx} C$ encoded protein is essential for the bacterium to elicit these phenotypes in planta.

Studies with a rhizobitoxine-producing pathogen, 
Burkholderia (formerly Pseudomonas) andropogonis, have suggested L-aspartate, L-homoserine, and L-threo-hydroxythreonine as possible intermediates in rhizobitoxine biosynthesis $^{52)}$. However, the proposed biosynthetic pathway needs additional yet-unidentified precursor(s), and genes involved in rhizobitoxine synthesis have not been isolated from B. andropogonis.

\section{ACC deaminase in rhizobia: alternative strategy for decreasing ethylene levels}

ACC deaminase degrades ACC (the immediate precursor of ethylene) into ammonia and $\alpha$-ketobutyrate (Fig. 2). Historically, ACC deaminase has been found and well characterized in plant-growth-promoting rhizobacteria (PGPR) ${ }^{18,76)}$. The ACC deaminase of PGPRs likely reduces the amount of ACC in associated roots and promotes root elongation via the decrease in ethylene production ${ }^{17}$.

The ability to synthesize rhizobitoxine is confined to the slow-growing $B$. elkanii among rhizobia so far. Thus, Yasuta et al. ${ }^{97)}$ addressed the question as to whether fastgrowing rhizobia possess another inhibitory factor for ethylene biosynthesis of host plants, because it could enhance nodulation ${ }^{56)}$. They sought potential enzymes and com- pounds for reducing ethylene biosynthesis from the entire genome of the fast-growing M. loti MAFF303099 presented in a database ${ }^{32)}$, and identified ACC deaminase gene as a candidate ${ }^{88}$. Indeed, ACC deaminase was verified to enhance nodulation and competitiveness to the host legume by using a disruption mutant of ACC deaminase gene $(\mathrm{m} l \mathrm{r} 5932)^{88)}$. Recently, genes encoding ACC deaminase have been also found in other rhizobia, such as Rhizobium leguminosarum and Bradyrhizobium japonicum ${ }^{33,44,45)}$. ACC deaminase from Rhizobium leguminosarum bv. viciae has been confirmed to enhance nodulation of Pisum sativum as well $^{44)}$.

These recent findings on ACC deaminase suggest that rhizobia can adopt more than one strategy to reduce the amount of ethylene synthesized by their host legumes and thus enhance nodule formation. Indeed, since many processes in nodule formation are blocked by ethylene, it seems reasonable that, in order to enable efficient nodulation, rhizobia would decrease ethylene levels by producing both ACC deaminase and rhizobitoxine.

Table 2. Rhizobial strategy for lowering ethylene in host plants

\begin{tabular}{|c|c|c|c|c|c|c|}
\hline Rhizobia & Strain & Gene $^{\mathrm{a}}$ & Expression $^{\mathrm{b}}$ & Activity $^{c}$ & $\begin{array}{l}\text { Plant showing nodulation } \\
\text { enhancement }^{\mathrm{d}}\end{array}$ & Reference \\
\hline \multirow[t]{2}{*}{ Bradyrhizobium elkanii } & USDA94 & $r t x A, r t x C$ & $\sigma^{70}$ & Free/Symbiosis & $\begin{array}{l}\text { Macroputilium atropurpurium } \\
\text { cv. Siratro }\end{array}$ & $57,58,96,98$ \\
\hline & USDA61 & $r t x A$ & & Free/Symbiosis & $\begin{array}{l}\text { Vigna radiata, Amphicarpaea } \\
\text { edgeworthii }\end{array}$ & $10,67,71$ \\
\hline \multirow[t]{2}{*}{ Bradyrhizobium japonicum } & USDA110 & $\begin{array}{l}\text { Fragmented } r t x A, \\
r t x C\end{array}$ & None & Not detected & & 20,33 \\
\hline & USDA110 & acdS (blr0241) & $\sigma^{70} /$ LRP & (Free/Symbiosis) & & 33 \\
\hline \multirow[t]{2}{*}{ Mesorhizobium loti } & MAFF303099 & $\operatorname{acd} S(\mathrm{~m} l \mathrm{r} 5932)$ & $\sigma^{54} / \mathrm{UAS}$ & Symbiosis & Lotus japonicus MG20 & 32,88 \\
\hline & $\mathrm{R} 7 \mathrm{~A}$ & $a c c D$ & $\sigma^{54} / \mathrm{UAS}$ & (Symbiosis) & & 83 \\
\hline $\begin{array}{l}\text { Rhizobium leguminosarum } \\
\text { bv. viciae }\end{array}$ & $128 \mathrm{C} 53 \mathrm{~K}$ & $a c d S$ & $\sigma^{70} /$ LRP & Free/(Symbiosis) & Pisum sativum L cv. Sparkle & 44,45 \\
\hline Rhizobium radiobacter ${ }^{\mathrm{e}}$ & $\mathrm{d} 3$ & $a c d S$ & $\sigma^{70} / \mathrm{LRP}$ & & & 87 \\
\hline
\end{tabular}

${ }^{a}$ Parenthesis indicates gene number of RHIZOBASE in Kazusa DNA research institute ${ }^{32,33)}$. $r t x A C$ genes are rhizobitoxine biosynthesis genes, while $a c d S$ and $a c c D$ genes encode ACC deaminase protein.

${ }^{\mathrm{b}}$ Mode of gene expression predicted by DNA sequences. $\sigma^{70}$ means $-35 /-10$ promoter. LRP (Leucine-responsible regulatory protein) indicates a negative regulatory system with LRP box. UAS and $\sigma^{54}$ indicate upstream activating sequence (NifA-binding site) and consensus sequences of $\sigma^{54}$ promoter (-24/-12 promoter).

${ }^{c}$ Activities of rhizobitoxine biosynthesis and ACC deaminase in free-living cells (Free) and bacteroids (Symbiosis). Data in parenthesis are deduced from promoter structures.

${ }^{d}$ Plant species showing nodulation enhancement by rhizobitoxine production or ACC deaminase activity. The nodulation enhancement was verified by the parent strain and disruption mutant of rhizobia.

${ }^{\mathrm{e}}$ Formerly, Agrobacterium tumefaciens ${ }^{73)}$ 


\section{Distribution and expression of genes involved in the synthesis of rhizobitoxine and ACC deaminase in rhizobia}

The distributions of genes involved in the synthesis of rhizobitoxine and ACC deaminase are summarized in Table 2. The $r t x$ genes involved in rhizobitoxine biosynthesis have been found in $B$. elkanii USDA9496), USDA61 ${ }^{71}$ and $B$. japonicum USDA1 $10^{20,33)}$. The fact that all strains of $B$. elkanii isolated from soybean nodules produce rhizobitoxine in culture and in planta ${ }^{46,47)}$ indicates that $B$. elkanii commonly carry $r t x$ genes. On the other hand, the situation regarding the existence and function of $r t x$ genes in B. japonicum is complex. Genome sequencing revealed the presence of $r t x$ genes in the B. japonicum USDA110 chromosome, although this bacterium does not produce rhizobitoxine ${ }^{46,477}$. Perhaps partial disruption of $r t x$ genes has caused them to lose the ability to biosynthesize rhizobitoxine ${ }^{96}$. In addition, some strains of B. japonicum, such as USDA122, lack the entire $r t x$ region (Minamisawa et al. unpublished results).

The rhizobitoxine genes of $B$. elkanii USDA94 are located in the symbiosis locus of the genome and are preceded by nodulation genes ${ }^{96}$. However, the rhizobitoxine operon in B. elkanii USDA94 is likely to have no regulatory system, because it is expressed constitutively (Sugawara, unpublished data), which is supported by the presence of a $\sigma^{70}$ promoter (-35/-10 general promoter) and the production of rhizobitoxine in both free-living cells and bacteroids (Table 2). The synthesis of rhizobitoxine depends on the presence of amino acids such as homoserine ${ }^{96)}$, which suggests that most rhizobitoxine production occurs in the rhizosphere and in plant tissues and little if any occurs in oligotrophic environments such as bulk soils.

Genes encoding ACC deaminase have been found in $B$. japonicum, M. loti, and $R$. leguminosarum (Table 2). ACC deaminase genes in M. loti strains MAFF303099 and R7A are preceded by a NifA-dependent $\sigma^{54}$ promoter and thus appear to be expressed only in the symbiotic state ${ }^{83,88}$. Indeed, the ACC deaminase gene of M. loti MAFF303099 was drastically upregulated in bacteroids compared with the level of its transcription in free-living cells ${ }^{88}$. ACC deaminase activity was detected exclusively in bacteroids of wild type of M. loti MAFF30309988). On the other hand, the ACC deaminase gene in $B$. japonicum and $R$. leguminosarum possesses a $\sigma^{70}$ promoter with an LRP (leucine-responsible regulatory protein) box ${ }^{33,44)}$ (Table 2). Since the promoter structure of $\sigma^{70} / \mathrm{LRP}$ was involved in ACC induction of ACC deaminase gene in R. leguminosarum and Entrobactor cloaca $^{44,45)}$, ACC is probably an inducer of the gene in
B. japonicum chromosome (Table 2). Recently, proteome analysis of B. japonicum bacteroids demonstrated that ACC deaminase is one of major proteins in bacteroids rather than free-living cells ${ }^{28}$, suggesting that ACC in host plants might induce the ACC deaminase gene in rhizobia. Interestingly, a pathogen of Rhizobium radiobacter (formerly, Agrobacterium tumefaciens) strain $\mathrm{d} 3$ harbored acdS gene preceded by $\sigma^{70} / \mathrm{LRP}$ as well ${ }^{87)}$ (Table 2 ).

\section{Mechanisms for nodulation enhancement}

Rhizobitoxine is secreted outside rhizobial cells, probably by a rhizobitoxine transporter (Fig. 3), and delivered to the plant. In fact, rhizobitoxine has been detected in leaves as well as in nodules of soybeans inoculated with $B$. elkanii ${ }^{48}$. Moreover, ethylene evolution is blocked in legume root systems inoculated with B. elkanii ${ }^{98}$. Therefore, the explanation of how rhizobitoxine decreases endogenous levels of ethylene in legume roots appears straightforward. A model has been proposed for decreasing and adjusting endogenous ethylene levels in plant roots by rhizobial ACC deaminase. This was deduced by a diffusion model that ACC in plant roots is up-taken and decomposed in PGPR $P$. putida ${ }^{17,18}$. So far there is no direct evidence for decreased ethylene evolution after bacterial inoculation that can be attributed to ACC deaminase.

The next question is how a decreased ethylene level enhances nodulation. Recently, several models have been proposed depicting the relationships between signal transduction, ethylene sensing, and the development of nodulation ${ }^{21,23,80}$. One promising approach will be to construct transgenic legumes with altered ethylene sensitivities. The expression of ethylene receptors that cannot bind ethylene confers reduced ethylene sensitivity to heterologous plants in a genetically dominant manner ${ }^{2}$. In petunia and tomato, transformation with a mutant Arabidopsis ethylene receptor gene (etrl-1) conferred reduced sensitivity to ethylene ${ }^{92)}$.

To address the mechanism by which ethylene inhibits nodulation, Nukui et al. ${ }^{55)}$ transformed L. japonicus B-129 'Gifu' ${ }^{26)}$ with a mutated ethylene receptor gene Cm-ERSI/ $H 70 A$ : A point mutation was introduced into the melon ethylene receptor $C m-E R S 1^{72)}$ by changing the 70th amino acid, histidine, to alanine, which abolished its ethylene-binding ability. The resultant transgenic $L$. japonicus plants showed reduced ethylene sensitivity. When inoculated with $M$. loti, the transgenic L. japonicus produced markedly higher numbers of infection threads and nodule primordia on their roots than did either wild-type or azygous plants 


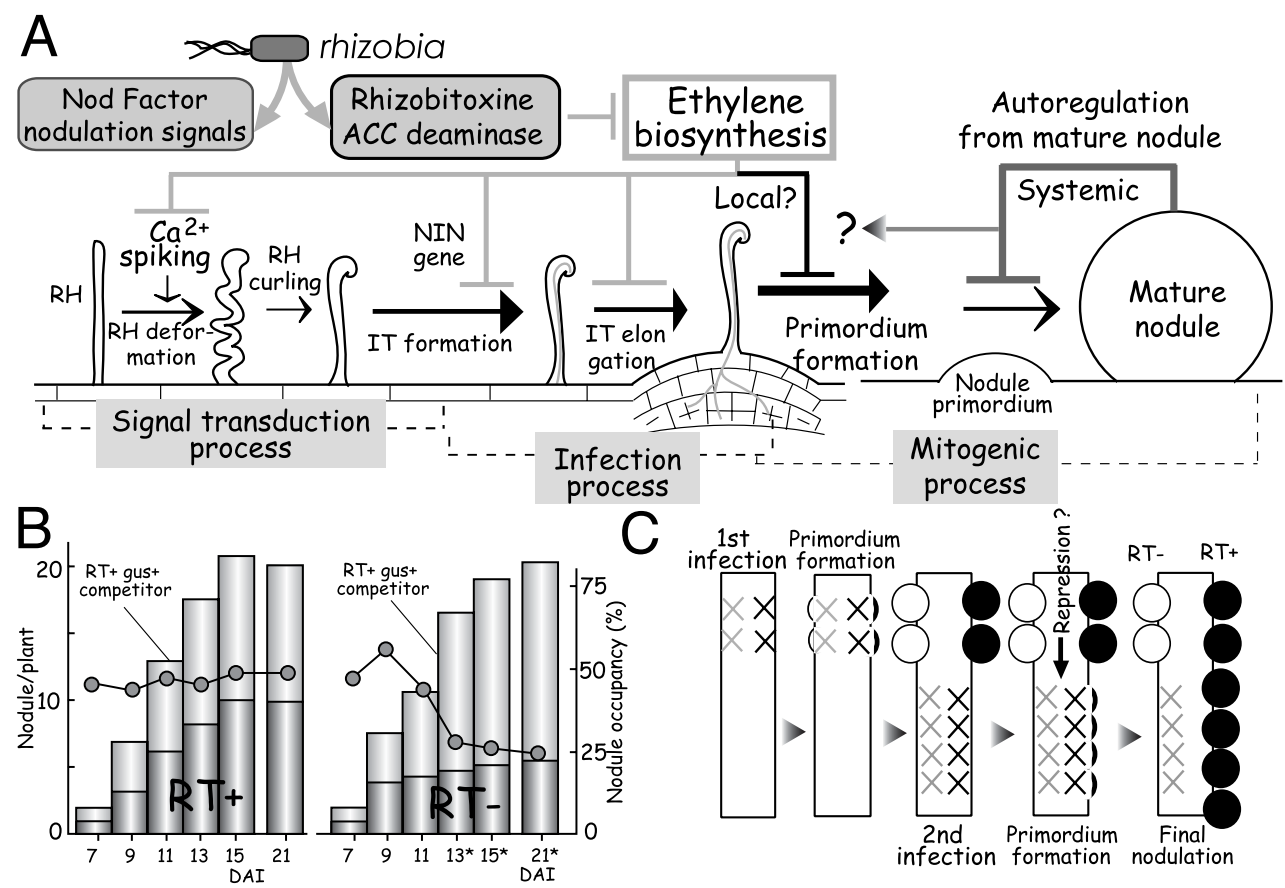

Fig. 4. Schematic presentations for a mechanism of ethylene inhibition of nodulation (A) and enhancement of nodulation competitiveness by rhizobitoxine (RT) production (B and C). (A) RH, root hair; IT, infection thread. In addition to nodulation signals (Nod factors, Fig. 1), rhizobia produce rhizobitoxine and/or ACC deaminase to reduce local ethylene levels by targeting ethylene biosynthesis in the host plants. High levels of endogenous ethylene would negatively regulate signal transduction, infection, and mitogen processes during rhizobia-legume interactions. In addition to the inhibition of nodulation by ethylene, nodule numbers in legumes already infected with rhizobia are strictly regulated by unknown factors from mature nodules (autoregulation) to maintain mutual symbiosis by both partners. (B) Time-course of nodule numbers (per plant) in competitive nodulation by a rhizobitoxine (RT)-producing strain (RT+) and non-producer (RT-) as compared with a reference strain (RT+/gus+ competitor) ${ }^{58}$. Line graphs indicate the nodule occupancy percentage during nodulation. (C) A proposed model for rhizobitoxine enhancement of competitive nodulation. Black and white (or gray) indicate the rhizobitoxine (RT) producing strain (RT+) and non-producer (RT-), respectively. The cross, swelling and circle show infection focus, nodule primordium and mature nodule, respectively. The rhizobitoxine-producing $(\mathrm{RT}+)$ strain may locally overcome the repression of primordia formation at a stage of secondary infection, resulting in higher nodule occupancy of the RT+ strain.

without the transgene. In addition, the amount of transcripts of NIN, a gene governing formation of infection threads ${ }^{74)}$, increased in the inoculated transgenic plants as compared with the wild-type plants. These results imply that endogenous ethylene in L. japonicus roots inhibits the formation of nodule primordia, as well as other infection processes ${ }^{55}$ (Fig. 4A).

So far, ethylene inhibition of nodulation has been studied by using chemical treatments (Table 1), ethylene-insensitive mutants $^{68}$, and transformants with reduced ethylene sensitivity ${ }^{55}$. These studies have revealed the existence of several target processes that ethylene inhibits: signal transduction at the beginning of nodulation, the infection process, and mitogenic processes (Fig. 4A). In particular, the marked enhancement of primordium formation observed in later stages of nodulation ${ }^{55}$ suggests that the mitogenic processes are deeply involved in ethylene inhibition of nodule formation (Fig. 4A).

The inhibition of nodulation by ethylene is thought to be independent of feedback regulation during nodulation termed as "autoregulation" ${ }^{6,35,54)}$ for the following reasons: (i) two hypernodulated mutants, sunn of Medicago truncatula ${ }^{69)}$ and harl of L. japonicus ${ }^{93)}$, showed normal sensitivity to ethylene, although a hyperinfected sickle mutant of M. truncatula is insensitive to ethylene ${ }^{68)}$; (ii) the number of mature nodules on the L. japonicus transformant showing reduced ethylene sensitivity remained restricted, although the transformant had dramatically increased numbers of nodule primordia ${ }^{55}$.

\section{Enhancement of nodulation competitiveness}

When mixed populations of diverse rhizobial strains exist in soil, certain strains can selectively infect and form nod- 
ules on host legumes. The ability of a certain strain to form nodules in a multi-strain environment is referred to as nodulation competitiveness. Nodulation competitiveness has practical importance in agriculture: rhizobial inoculants that are superior for efficient symbiotic nitrogen fixation are often nodulated poorly in fields, owing to the presence of better-competing populations of inferior rhizobia in soils ${ }^{81)}$.

Recent studies have revealed that both rhizobitoxine production by $B$. elkanii USDA94 and ACC deaminase activity in $M$. loti MAFF303099 significantly enhance their nodulation competitiveness on host legumes rather than nodulation by single inoculation ${ }^{58,88,98)}$. Enhancement of nodulation competitiveness by rhizobitoxine in siratro (Macroptillium atropurpureum) occurs at a late stage during nodulation (Fig. 4B), but does not affect cell growth in the rhizosphere ${ }^{58)}$. All other known rhizobial factors that affect nodulation competitiveness act in the rhizosphere and during the initial interaction with legumes, such as production of antibiotics or bacteriocin, cell surface characteristics, and motility ${ }^{85,86)}$.

Although it is still unclear how rhizobitoxine production and ACC deaminase activity affect nodulation competitiveness, a possible explanation is that they block ethylene biosyntheis locally at the infection site and cancel the negative effects of ethylene on nodulation during the mitogenic processes. According to the result of B. elkanii USDA94 in Fig. $4 \mathrm{~B}$, a rhizobitoxine-producing strain may locally overcome the repression of primordia formation at a stage of secondary infection, resulting in higher nodule occupancy of the RT+ strain (Fig. 4C). However, many uncertainties remain (Fig. 4C). For example: Does the nodulation enhancement occur locally? Do many nodulation foci of RT-strain remain? Is secondary primordium formation repressed exclusively by the systemic autoregulation? Does ethylene inhibition on nodulation fluctuate during nodulation and/or legume growth stages? Are there different effects and mechanisms between rhizobitoxine and ACC deaminase?

\section{Coevolution of ethylene-mediated interactions between rhizobia and legumes}

The symbiosis between legumes and rhizobia has endured since the origin of ancient Leguminosae ${ }^{8}$. Cumulative evidence has shown that most economically important legumes possess a mechanism for the regulation of nodule formation by ethylene (Table 1, Fig. 4), although most varieties of soybeans are not subjected to such ethylene regulation. Recent studies in turn have indicated that rhizobial species have evolved relevant strategies to cope with ethyl- ene, that is, rhizobitoxine production and the expression of ACC deaminase. Ethylene-decreasing strategies have been found at least in three genera of rhizobia (Table 2), which implies that this strategy has been beneficial for rhizobia as they have coevolved with host legume species.

Parker and Peters ${ }^{67)}$ presented an interesting observation relevant to the evolution of symbiotic compatibility. A Japanese population of the legume Amphicarpaea edgeworthii formed few or no nodules with North American bradyrhizobial strains that did not produce detectable levels of rhizobitoxine. However, all North American A. bracteata lineages formed efficient nodules with Japanese Bradyrhizobium strains that produce rhizobitoxine and which were isolated from A. edgeworthii. They speculated that A. edgeworthii has adapted to an environment in which rhizobitoxine-producing rhizobia are prevalent and that long-term geographic isolation might lead to changes in symbiotic compatibility.

Incompatible symbioses between $B$. elkanii and modern cultivars of soybean appear to be an alternative example of coevolution. Rhizobitoxine-producing $B$. elkanii induce foliar chlorosis in modern cultivars of soybean ${ }^{11,95)}$, however, these soybeans are compatible with $B$. japonicum, which does not produce rhizobitoxine. It is possible that, as compatibility with $B$. japonicum strains has been bred into modern cultivars of soybean, they have concomitantly become sensitive to rhizobitoxine-inducing chlorosis. Interestingly, B. japonicum USDA110 possesses partially collapsed $r t x$ genes $^{96)}$, suggesting that an ancestor of $B$. japonicum that had the ability to produce rhizobitoxine. $B$. japonicum probably lost the ability to produce rhizobitoxine during the coevolutionary process with soybeans, because rhizobitoxine plays no beneficial role but has the harmful effect of chlorosis induction on soybeans.

\section{Exploitation of rhizobial strategies}

If some rhizobial strains lack the ability to decrease ethylene levels in host legumes, the introduction of genes for rhizobitoxine biosynthesis and ACC deaminase into these rhizobia ought to enhance their symbiotic interactions with host legumes. This idea may also be extended to other plantassociated bacteria, such as Rhizobium radiobacter (formerly Agrobacterium tumefaciens), which has been used for plant transformation. Indeed, application of AVG, an analog of rhizobitoxine, increased the efficiency of Agrobacteriummediated gene transfer to explants of melons ${ }^{12)}$. The ethylene-decreasing strategies of rhizobia are interesting and suggestive for the further understanding of plant-microbe interactions and should be a promising tool for overcoming 
the problem of rhizobial competition and for making further progress toward developing more environmentally friendly biotechnology and agriculture.

\section{Acknowledgements}

This work was supported in part by grants to K. M. from the Ministry of Education, Science, Sports, and Culture of Japan (nos. 11556012 and 14360037) and by a Research Fellowship of the Japan Society for the Promotion of Young Scientists to N. N.. We thank PROBRAIN (Japan) for supporting the research of K. M.. We are grateful to K. Yuhashi and H. Ezura (Tsukuba University) for their collaboration and helpful discussions for ethylene perception and competitive nodulation, to H. Mitsui (Tohoku University) for his helpful discussions on rhizobial gene regulation, to K. Saeki (Osaka University) for a gift of gfp-tagged M. loti strain, and to B. Ye (Tohoku University) for the electron micrograph included in Fig. 1.

\section{References}

1) Abeles, F.B., P.W. Morgan and M.E. Saltveit Jr. 1992. Ethylene in plant biology, Ed 2. Academic Press, New York, N.Y.

2) Bleecker, A. 1999. Ethylene perception and signaling: an evolutionary perspective. Trends Plant Sci. 4: 269-274.

3) Bohlool, B.B., J.K. Ladha, D.P. Garrity and T. George. 1992. Biological nitrogen fixation for sustainable agriculture: a perspective. Plant Soil 141: 1-11.

4) Bras, C.P., M.A. Jorda., A.H.M. Wijfjes, M. Harteveld, N. Stuurman, J.E. Thomas-Oates and H.P. Spaink. 2000. A Lotus japonicus nodulation system based on heterologous expression of the fucosyl transferase NodZ and the acetyl transferase NolL in Rhizobium leguminosarum. Mol. Plant-Microbe Interact. 13: 475-479.

5) Caba, J.M., L. Recalde and F. Ligero. 1998. Nitrate-induced ethylene biosynthesis and the control of nodulation in alfalfa. Plant Cell Environ. 21: 87-93.

6) Caetano-Anolles, G. and M. Gresshoff. 1991. Plant genetic control of nodulation. Annu. Rev. Microbiol. 45: 345-382.

7) Devine, T.E. and B.H. Breithaut. 1980. Effect of the ethoxy ana$\log$ of rhizobitoxine on nodulation of soybeans. Crop Sci. 20: 819-821.

8) Doyle, J.J. 1998. Phylogenetic perspectives on nodulation: evolving views of plants and symbiotic bacteria. Trends Plant Sci. 3: 473-478.

9) Drennan, D.S.H. and C. Norton. 1972. The effect of Ethrel on nodulation in Pisum sativum L. Plant Soil 36: 53-57.

10) Duodu, S., T.V. Bhuvaneswari, T.J.W. Stokkermans and N.K. Peters. 1999. A positive role for rhizobitoxine in Rhizobiumlegume symbiosis. Mol. Plant-Microbe Interact. 12: 1082-1089.

11) Erdman L.W., H.W. Johnson and F. Clark. 1956. A bacterialinduced chlorosis in the Lee soybean. Plant Dis. Rep. 40: 646.

12) Ezura, H., K. Yuhashi, T. Yasuta and K. Minamisawa. 2000. Effect of ethylene on Agrobacterium tumefaciens-mediated gene transfer to melon. Plant Breeding 119: 75-79.
13) Fearn, J.C. and T.A. LaRue. 1991. Ethylene inhibitors restore nodulation to sym 5 mutants of Pisum sativum L. cv Sparkle. Plant Physiol. 96: 239-244.

14) Fernandez-Lopez, M., S. Goormachtig, M. Gao, W.D. Haeze, M.V. Montagu and M. Holsters. 1998. Ethylene-mediated phenotypic plasticity in root nodule development on Sesbania rostrata. Proc. Natl. Acad. Sci. USA 95: 12724-12728.

15) Fisher, R.F. and S.R. Long. 1992. Rhizobium — plant signal exchange. Nature 357: 655-660.

16) Giovanelli, J., L.D. Owens and S.H. Mudd. 1972. $\beta$-cystathionase: in vivo inactivation by rhizobitoxine and role of the enzyme in methionine biosynthesis in corn seedlings. Plant Physiol. 51: 492-503.

17) Glick, B.R., C.B. Jacobson and M.M.K. Schwarze. 1994. 1Aminocyclopropane-1-carboxylic acid deaminase mutants of the plant growth promoting rhizobacterium Pseudomonas putida GR12-2 do not stimulate canola root elongation. Can. J. Microbiol. 40: 911-915.

18) Glick, B.R., D.M. Karaturovic and P.C. Newell. 1995. A novel procedure for rapid isolation of plant growth-promoting pseudomonads. Can. J. Microbiol. 41: 533-536.

19) Goodlass, G. and K.A. Smith. 1979. Effects of ethylene on root extension and nodulation of pea (Pisum sativum L.) and white clover (Trifolium repens L.). Plant Soil 51: 387-395.

20) Gottfert, M., S. Rothlisberger, C. Kundig, C. Beck, R. Marty and H. Hennecke. 2001. Potential symbiosis-specific genes uncovered by sequencing a 410-kilobase DNA region of the Bradyrhizobium japonicum chromosome. J. Bacteriol. 183: 1405-1412.

21) Gresshoff, P.M., R.J. Rose, M. Singh and B.G. Rolfe. 2003. Symbiosis signals. Todays' LifeScience May/June, http:// cirl.rsbs.anu.edu.au/News/tls0503Gresshoff HR.pdf

22) Grobbelaar, N., B. Clarke and M.C. Hough. 1971. The nodulation and nitrogen fixation of isolated roots of Phaseolus vulgaris L. III. The effect of carbon dioxide and ethylene. Plant Soil (Special volume): $215-223$.

23) Guinel, F.C. and R.D. Geil. 2002. A model for the development of the rhizobial and arbuscular mycorrhizal symbioses in legumes and its use to understand the roles of ethylene in the establishment of these two symbioses. Can. J. Bot. 80: 695-720.

24) Guinel, F.C. and T.A. LaRue. 1992. Ethylene inhibitors partly restore nodulation to pea mutant E107 (brz). Plant Physiol. 99: $515-518$

25) Guinel, F.C. and L.L. Sloetjes. 2000. Ethylene is involved in the nodulation phenotype of Pisum sativum R50 (sym 16), a pleiotropic mutant that nodulates poorly and has pale green leaves. J. Exp. Bot. 51: 885-894.

26) Handberg, K. and J. Stougaard. 1992. Lotus japonicus, an autogamous, diploid legume species for classical and molcular genetics. Plant J. 2: 487-496.

27) Heidstra, R., W.C. Yang, Y. Yalcin, S. Peck, A.M. Emons, A. van Kammen and T. Bisseling. 1997. Ethylene provides positional information on cortical cell division but is not involved in Nod factor-induced root hair tip growth in Rhizobium-legume interaction. Development 124: 1781-1787.

28) Hoa L.T-P., M. Nomura and S. Tajima. 2004. Characterization of bacteroid proteins in soybean nodules formed with Bradyrhizobium japonicum USDA110. Microbes. Environ. 19: 71-75.

29) Hollis, T. A., W. E. Kloos and G. E. Elkan. 1981. DNA:DNA hybridization studies of Rhizobium japonicum and related Rhizobiaceae. J. Gen. Microbiol. 123: 215-222. 
30) Hunter W.J. 1993. Ethylene production by root nodules and effect of ethylene on nodulation in Glycine max. Appl. Environ. Microbiol. 59: 1947-1950.

31) Johnson, H.W., U.M. Means and F.E. Clark. 1959. Responses of seedlings to extracts of soybean nodules bearing selected strains of Rhizobium japonicum. Nature 183: 308-309.

32) Kaneko, T., Y. Nakamura, S. Sato, E, Asamizu, T. Kato, S. Sasamoto, A. Watanabe, K. Idesawa, A. Ishikawa, K. Kawashima, T. Kimura, Y. Kishida, C. Kiyokawa, M. Kohara, M. Matsumoto, A. Matsuno, Y. Mochizuki, S. Nakayama, N. Nakazaki, S. Shimpo, M. Sugimoto, C. Takeuchi, M. Yamada and S. Tabata. 2000. Complete genome structure of the nitrogenfixing symbiotic bacterium Mesorhizobium loti. DNA Res. 7: 331-338.

33) Kaneko T, Y. Nakamura, S. Sato, K. Minamisawa, T. Uchiumi, S. Sasamoto, A. Watanabe, K. Idesawa, M. Iriguchi, K. Kawashima, M. Kohara, M. Matsumoto, S. Shimpo, H. Tsuruoka, T. Wada, M. Yamada and S. Tabata. 2002. Complete genomic sequence of nitrogen-fixing symbiotic bacterium Bradyrhizobium japonicum USDA110. DNA Res. 31: 189-197.

34) Kinzig, A.P. and R.H. Socolow. 1994. Phys. Today 47: 24-35.

35) Krusell, L., L.H. Madsen, S. Sato, G. Aubert, A. Genua, K. Szczyglowski, G. Duc, T. Kaneko, S. Tabata, F. de Bruijn, E. Pajuelo, N. Sandal and J. Stougaard. 2002. Shoot control of root development and nodulation is mediated by a receptor-like kinase. Nature 420: 422-426.

36) Lee, K.H. and T.A. LaRue. 1992. Ethylene as a possible mediator of light- and nitrate-induced inhibition of nodulation of Pisum sativum L. cv Sparkle. Plant Physiol. 100: 1334-1338.

37) Lee, K.H. and T.A. LaRue. 1992. Exogenous ethylene inhibits nodulation of Pisum sativum L. cv Sparkle. Plant Physiol. 100: 11759-11763.

38) Ligero, F., C. Lluch and J. Olivares. 1986. Evolution of ethylene from roots of Medicago sativa plants inoculated with Rhizobium meliloti. J. Plant Physiol. 125: 361-365.

39) Ligero, F., C. Lluch and J. Olivares. 1987. Evolution of ethylene from roots and nodulation rate of alfalfa (Medicago sativa $\mathrm{L}$.) plants inoculated with Rhizobium meliloti as affected by the presence of nitrate. J. Plant Physiol. 129: 461-467.

40) Ligero, F., J.M. Caba, C. Lluch and J. Olivares. 1991. Nitrate inhibition of nodulation can be overcome by the ethylene inhibitor aminoethoxyvinylglycine. Plant Physiol. 97: 1221-1225.

41) Ligero, F., J.L. Poveda, P.M. Gresshoff and J.M. Caba. 1999. Nitrate- and inoculation-enhanced ethylene biosynthesis in soybean roots as a possible mediatore of nodulation control. J. Plant Physiol. 154: 482-488.

42) Long, S.R. 1989. Rhizobium - legume nodulation: life together in the underground. Cell 56: 203-214.

43) Lorteau, M.A., B.J. Ferguson and F.C. Guinel. 2001. Effects of cytokinin on ethylene production and nodulation in pea (Pisum sativum) cv. Sparkle. Physiol. Plant. 112: 421-428.

44) Ma, W., F.C. Guinel and B.R. Glick. 2003. Rhizobium leguminosarum biovar viciae 1-aminocyclopropane-carboxylate deaminase promotes nodulation of pea plants. Appl. Environ. Microbiol. 69: 4396-4402.

45) Ma, W., S.B. Sebestianova, J. Sebestian, G.I. Burd, F.C. Guinel and B.R. Glick. 2003. Prevalence of 1-aminocyclopropane-carboxylate deaminase in Rhizobium spp. Antonie van Leeuwenhoek 83: 285-291.

46) Minamisawa, K. 1989. Comparison of extracellular polysaccharide composition, rhizobitoxine production, and hydrogenase phenotype among various strains of Bradyrhizobium japonicum. Plant Cell Physiol. 30: 877-884.

47) Minamisawa, K. 1990. Division of rhizobitoxine-producing and hydrogen-uptake positive strains of Bradyrhizobium japonicum by nifDKE sequence divergence. Plant Cell Physiol. 31: 81-89.

48) Minamisawa, K. and N. Kume. 1987. Determination of rhizobitoxine and dihydrorhizobitoxine in soybean plants by amino acid analyzer. Soil Sci. Plant Nutr. 33: 645-649.

49) Minamisawa, K. and H. Mitsui. 2000. Genetic ecology of soybean bradyrhizobia. pp. 349-377. In J.-M. Bollag and G. Stotzky (ed.), Soil biochemistry. Marcel Dekker, New York, N.Y.

50) Minamisawa, K. and H. Watanabe. 1986. Serinol (2-amino-1,3propanediol) and 3-amino-1,2-propanediol in soybean nodules. Plant Cell Physiol. 27: 1109-1116.

51) Mitchell, R.E. and E.J. Frey. 1988. Rhizobitoxine and hydroxythreonine production by Pseudomonas andropogonis strains, and the implications to plant disease. Physiol. Mol. Plant Pathol. 32: 335-341.

52) Mitchell, R.E., E.J. Frey and M.K. Benn. 1986. Rhizobitoxine and 1-threo-hydroxythrionine production by the plant pathogen Pseudomonas andropogonis. Phytochemistry 25: 2711-2715.

53) Mosier, A.R., J.M. Duxbury, J.R. Freney, O. Heinemeyer and K. Minami. 1996. Nitrous oxide emissions from agricultural fields: assessment, measurement and mitigation. Plant Soil 181: 95-108.

54) Nishimura, R., M. Hayashi, G. Wu, H. Kouchi, H. ImaizumiAnraku, Y. Murakami, S. Kawasaki, S. Akao, M. Ohmori, M. Nagasawa, K. Harada and M. Kawaguchi. 2002. HAR1 mediates systemic regulation of symbiotic organ development. Nature 420: 426-429.

55) Nukui, N., H. Ezura and K. Minamisawa. 2004. Transgenic Lotus japonicus with an ethylene receptor gene Cm-ERS1/H70A enhances formation of infection threads and nodule primordia. Plant Cell Physiol. 45: 427-435.

56) Nukui, N., H. Ezura, K. Yuhashi, T. Yasuta and K. Minamisawa. 2000. Effect of ethylene precursor and inhibitors for ethylene biosynthesis and perception on nodulation in Lotus japonicus and Macroptilium atropurpureum. Plant Cell Physiol. 41: 893-987.

57) Okazaki S., M. Sugawara and K. Minamisawa. 2004. Bradyrhizobium elkanii rtxC gene is required for expression of symbiotic phenotypes in the final step of rhizobitoxine biosynthesis. Appl. Environ. Microbiol. 70: 535-541.

58) Okazaki S., K. Yuhashi and K. Minamisawa. 2003. Quantitative and time-course evaluation of nodulation competitiveness of rhizobitoxine-producing Bradyrhizobium elkanii. FEMS Microbiol. Ecol. 45: 155-160.

59) Oldroyd, G.E., E.M. Engstrom and S.R. Long. 2001. Ethylene inhibits the Nod factor signal transduction pathway of Medicago truncatula. Plant Cell 13: 1835-1849.

60) Owens, L.D. 1973. Herbicidal potential of rhizobitoxine. Weed Sci. 21: 63-66.

61) Owens, L.D., S. Guggenheim and J.L. Hilton. 1968. Rhizobiumsynthesized phytotoxin: an inhibitor of $\beta$-cystathionase in Salmonella typhimurium. Biochim. Biophys. Acta 158: 219-225.

62) Owens, L.D., M. Lieberman and A. Kunishi. 1971. Inhibition of ethylene production by rhizobitoxine. Plant Physiol. 48: 1-4.

63) Owens, L.D., J.F. Thompson and P.V. Fennessy. 1972. Dihydrorhizobitoxine, a new ether amino-acid from Rhizobium japonicum. J. Chem. Soc., Chem. Commun. 1972: 715.

64) Owens, L.D., J.F. Thompson, R.G. Pitcher and T. Williams. 1972. Structure of rhizobitoxine, an antimetabolic enol-ether amino acid from Rhizobium japonicum. J. Chem. Soc., Chem. 
Commun. 1972: 714.

65) Owens, L.D. and D.A. Wright. 1965. Rhizobial-induced chlorosis in soybeans: isolation, production in nodules, and varietal specificity of the toxin. Plant Physiol. 40: 927-930.

66) Owens, L.D. and D.A. Wright. 1965. Production of the soybeanchlorosis toxin by Rhizobium japonicum in pure culture. Plant Physiol. 40: 931-933.

67) Parker, M.A. and N.K. Peters. 2001. Rhizobitoxine production and symbiotic compatibility of Bradyrhizobium from Asian and North American lineages of Amphicarpaea. Can. J. Microbiol. 47: 1-6.

68) Penmetsa, R.V. and D.R. Cook. 1997. A legume ethylene-insensitive mutant hyperinfected by its rhizobial symbiont. Science 275: 527-530.

69) Penmetsa, R.V., J.A. Frugoli, L.S. Smith, S.R. Long and D.R. Cook. 2003. Dual genetic pathways controlling nodule number in Medicago truncatula. Plant Physiol. 131: 998-1008.

70) Peters, N.K. and D.K. Crist-Estes. 1989. Nodule formation is stimulated by the ethylene inhibitor aminoethoxyvinylglycine. Plant Physiol. 91: 690-693.

71) Ruan, X. and N.K. Peters. 1992. Isolation and characterization of rhizobitoxine mutants of Bradyrhizobium japonicum. J. Bacteriol. 174: 3467-3473.

72) Sato-Nara, K., K.-I. Yuhashi, K. Higashi, K. Hosoya, M. Kubota and H. Ezura. 1999. Stage- and tissue-specific expression of ethylene receptor homolog genes during fruit development in muskmelon. Plant Physiol. 120: 321-330.

73) Sawada, H., L.D. Kuykendall and J.M. Young. 2003. Changing concepts in the systematics of bacterial nitrogen-fixing legume symbionts. J. Gen. Appl. Microbiol. 49: 155-179.

74) Schauser, L., A. Roussis, J. Stiller and J. Stougaard. 1999. A plant regulator controlling development of symbiotic root nodules. Nature 402: 191-195.

75) Schmidt, J.S., J.E. Harper, T.K. Hoffman and A.F. Bent. 1999 Regulation of soybean nodulation independent of ethylene signaling. Plant Physiol. 119: 951-959.

76) Shah, S., J. Li, B.A. Maffatt and B.R. Glick. 1998. Isolation and characterization of ACC deaminase genes from two different plant growth-promoting bacteria. Can. J. Microbiol. 44: 833-843.

77) Spaink, H.P. 1996. Regulation of plant morphogenesis by lipo-chitin oligosaccharides. Crit. Rev. Plant Sci. 15: 559-582.

78) Spaink, H.P. 1997. Ethylene as a regulator of Rhizobium infection. Trends Plant Sci. 2: 203-204.

79) Spaink, H.P. 2000. Root nodulation and infection factors produced by rhizobial bacteria. Annu. Rev. Microbiol. 54: 257-288.

80) Stearns, J.C. and B.R. Glick. 2003. Transgenic plants with altered ethylene biosynthesis or perception. Biotechnol. Adv. 21: 193210.

81) Streeter, J.G. 1994. Failure of inoculant rhizobia to overcome the dominance of indigenous strains for nodule formation. Can. J. Microbiol. 40: 513-522.

82) Suganuma N., H. Yamauchi and K. Yamamoto. 1995. Enhanced production of ethylene by soybean roots after inoculation with Bradyrhizobium elkanii. Plant Sci. 111: 163-168.

83) Sullivan, J.T., J.R. Trzebiatowski, R.W. Cruickshank, J. Gouzy, S.D. Brown, R.M. Elliot, D.J. Fleetwood, N.G. McCallum, U. Rossbach, G.S. Stuart, J.E. Weaver, R.J. Webby, F.J. De Bruijn and C.W. Ronson. 2002. Comparative sequence analysis of the symbiosis island of Mesorhizobium loti strain R7A. J. Bacteriol. 184: 3086-3095.

84) Tamimi, S.M. and M.P. Timko. 2003. Effects of ethylene and inhibitors of ethylene synthesis and action on nodulation in common bean (Phaseolus vulgaris L.). Plant Soil 257: 125-131.

85) Toro, N. 1996. Nodulation competitiveness in the Rhizobiumlegume symbiosis. World J. Microbiol. Biotechnol. 12: 157-162.

86) Triplett, E.W. and M.J. Sadowsky. 1992. Genetics of competition for nodulation of legumes. Annu. Rev. Microbiol. 46: 399-428.

87) Trott, S., R. Bauer, H.J. Knackmuss and A. Stolz. 2001. Genetic and biochemical characterization of an enantioselective amidase from Agrobacterium tumefaciens strain d3. Microbiology 147: 1815-1824.

88) Uchiumi, T., T. Oowada, M. Itakura, H. Mitsui, N. Nukui, P. Dawadi, T. Kaneko, S. Tabata, T. Yokoyama, T. Tejima, K. Saeki, H. Oomori, M. Hayashi, T. Maekawa, R. Sriprang, Y. Murooka, S. Tajima, K. Simomura, M. Nomura, A. Suzuki, S. Shimoda, K. Sioya, M. Abe and K. Minamisawa. 2004. Expression islands clustered on symbiosis island of Mesorhizobium loti genome. J. Bacteriol. 186: 2439-2448.

89) van Berkum, P. and B.D. Eardly. 1998. Molecular evolutionary systematics of the Rhizobiaceae. pp. 1-24. In H.P. Spaink, A. Kondorosi and P.J.J. Hooykaas (ed.), The Rhizobiaceae: molecular biology of model plant-associated bacteria. Kluwer, Dordrecht.

90) van Berkum, P., Z. Terefework, L. Paulin, S. Suomalainen, K. Lindstrom and B.D. Eardly. 2003. Discordant phylogenies within the $r r n$ loci of rhizobia. J. Bacteriol. 185: 2988-2998.

91) van Spronsen, P.C., A.A. van Brussel and J.W. Kijne. 1995. Nod factors produced by Rhizobium leguminosarum biovar viciae induce ethylene-related changes in root cortical cells of Vicia sativa ssp. nigra. Eur. J. Cell Biol. 68: 463-469.

92) Wilkinson, J.Q., M.B. Lanahan, D.G. Clark, A.B. Bleecker, C. Chang, E.M. Meyerowitz and H.J. Klee. 1997. A dominant mutant receptor from Arabidopsis confers ethylene insensitivity in heterologous plants. Nat. Biotechnol. 15: 444-447.

93) Wopereis, J., E. Pajuelo, F. Dazzo, Q. Jiang, P. Gresshoff, F. de Bruijn, J. Stougaard and K. Szczyglowski. 2000. Shoot root mutant of Lotus japonicus with a dramatically altered symbiotic phenotype. Plant J. 23: 97-114.

94) Xie Z.-P., C. Staehelin, A. Wiemken and T. Boller. 1996. Ethylene responsiveness of soybean cultivars characterized by leaf senescence, chitinase induction and nodulation. J. Plant Physiol. 149: 690-694.

95) Xiong K. and J.J. Fuhrmann. 1996. Comparison of rhizobitoxineinduced inhibition of $\beta$-cystathionase from different bradyrhizobia and soybean genotypes. Plant Soil 186: 53-61.

96) Yasuta, T., S. Okazaki, H. Mitsui, K. Yuhashi, H. Ezura and K. Minamisawa. 2001. DNA sequence and mutational analysis of rhizobitoxine biosynthesis gene in Bradyrhizobium elkanii. Appl. Environ. Microbiol. 67: 4999-5009.

97) Yasuta, T., S. Satoh and K. Minamisawa. 1999. New assay for rhizobitoxine based on inhibition of 1-aminocyclopropane-1carboxylate synthase. Appl. Environ. Microbiol. 65: 849-852.

98) Yuhashi, K., N. Ichikawa, H. Ezura, S. Akao, Y. Minakawa, N. Nukui, T. Yasuta and K. Minamisawa. 2000. Rhizobitoxine production by Bradyrhizobium elkanii enhances nodulation and competitiveness on Macroptilium atropurpureum. Appl. Environ. Microbiol. 66: 2658-2663.

99) Zaat, S.A.J., A.A.N. Van Brussel, B.J.J. Lugtenberg and J.W. Kijne. 1989. The ethylene-inhibitor aminoethoxyvinylglycine restores normal nodulation by Rhizobium leguminosarum biovar. viciae on Vicia sativa sub sp. Nigra by suppressing the 'Thick and short roots' phenotype. Planta 177: 141-150. 